\title{
Awareness of Climate Change and Sustainable Development among Undergraduates from two Selected Universities in Oyo State, Nigeria
}

\author{
Agboola, Omowunmi Sola ${ }^{1, *}$ \& Emmanuel, Michael ${ }^{1}$ \\ ${ }^{1}$ Institute of Education, Faculty of Education, Obafemi Awolowo University, Ile-Ife 220005, Nigeria \\ *Correspondence: Institute of Education, Faculty of Education, Obafemi Awolowo University, Ile-Ife 220005, \\ Nigeria. Tel: 234-806-500-8779. E-mail: omowunmisola@yahoo.co.uk
}

Received: February 3, 2016

Accepted: April 4, $2016 \quad$ Online Published: June 13, 2016

doi:10.5430/wje.v6n3p70

URL: http://dx.doi.org/10.5430/wje.v6n3p70

\begin{abstract}
This study investigated awareness of climate change and sustainable development among undergraduates in two universities: University of Ibadan, Ibadan and Ladoke Akintola University of Technology, Ogbomoso in Oyo State of Nigeria. This was aimed at increasing the knowledge of undergraduates on climate change and sustainable development.

The study adopted a survey design. The population for the study consisted of 300 hundred undergraduates in University of Ibadan, Ibadan and Ladoke Akintola University of Technology, Ogbomoso in Oyo State, Nigeria. The students were selected using purposively random sampling technique. A 45-item each with Likert type response format titled "Awareness of Climate Change and Sustainable Development among Undergraduates Students" tagged ACCSDUS were administered. Data obtained were analyzed using simple percentages and t-test.

The results showed that undergraduates possessed high level of awareness on the concept of climate change, have access to the sources of information and factors of personal experience, public sources and education greatly influence their awareness. The results further showed that there was no significant difference in the level of climate change and sustainable development awareness in term of gender $(t=0.733>0.05)$. There is a significant difference in the level of awareness of undergraduates on the concept of climate change based on school ownership $(\mathrm{t}=0.013<$ $0.05)$.

The study concluded that climate change education should be structured and embedded in the curricula of schools at all levels and that training, re-training, empowerment or enlightenment of the public and stakeholders in climate change should be carried out without bias, discrimination or marginalization of any form.
\end{abstract}

Keywords: awareness, climate change, sustainable development, undergraduates

\section{Introduction}

Climate change is an environmental, social and economic challenge on a global scale (Mendelsohn and Williams, 2006). The United States Environmental Protection Agency (USEPA, 2014) stated that Climate change refers to any significant change in the measures of climate lasting for an extended period of time. In other words, climate change includes major changes in temperature, precipitation, or wind patterns, among other effects, that occur over several decades or longer. Knutson (2011) referred to climate change research as a big endeavour because of its involvement with the entire planet and everything that affects their survival. The challenges posed by climate change crises constitute major threat to sustainable development. The concern of sustainable development relates to the need to face and save the future in order to keep and safeguard the interests of coming generations. Aliyu (2009) was of the opinion that climate change would constrain the ability of developing countries to attain their poverty reduction and sustainable development objectives under the United Nations Millenium Development Goals. There is a dual relationship between sustainable development and climate change. Climate change influences key natural and human living conditions and thereby also the basis for social and economic development while on the other hand society's priorities on sustainable development influence both the greenhouse gases (GHG) emissions that are causing climate change and vulnerability. The four most important greenhouse gases are carbon dioxide, methane, nitrous oxide and fluorinated gases. Human activities are responsible for almost all of the increase in greenhouse gases in the 
atmosphere over the last one hundred and fifty (150) years (IPCC, 2007). The largest source of gas emission is from burning fossil fuels for electricity, heat and transportation (USEPA, 2016).

The university is a high level centre for learning. It is expedient that university students are not ignorant of climate change issues as they relate to sustainable development. The awareness and possession of knowledge and understanding of climate change concepts and phenomena although scientific, are expedient for all humans, suffice to state that undergraduates assume the responsibility of transferring the knowledge when they graduate and practice their professions (Nath, 2009). According to the Climate Literacy Framework from the US Global Change Research Council, Climate Science Literacy is an understanding of your influence on climate and climate's influence on you and society (USGCRP, 2009). A climate literate person: understandings the essential principles of Earth's climate system, knows how to assess scientifically credible information about climate, communicates about climate and climate change in a meaningful way and is able to make informed and responsible decisions with regard to actions that may affect climate. Students can be part of the solutions of reducing greenhouse gas emissions. They are the ones that can tell people about the technologies that would reduce the amount of greenhouse gases being added to the atmosphere, actions to be taken to save energy and slow climate change and explore ways people can prepare for climate change. According to Nath (2009), University teachers have a special responsibility for instilling environmental awareness in all their students, graduate and undergraduate in all disciplines either by formal curricula or structured discussion. University students should be aware of the following: global environmental integrity, the "North-South" divide, global warming and climate change, acidification of the oceans and poverty eradication.

Curiosity about the environment and its sustenance is not science but the thirst for knowledge. All humans reserve the right to be curious about discovering as much as possible about our planet, and studying its inhabitants. Therefore, knowledge and awareness of climate change and associated concepts is an intellectual activity to be possessed by all regardless of the educational bias or background, sex, age, school ownership or level of education. As climate changes, everything changes from the natural habitat of wildlife to the culture and sustainable of a region. Some of the effects of climate change are sea level rise, changes in rainfall patterns, water scarcity and adverse health effects from warmer temperature (Marty and Yokochi, 2006). Climate change has a cumulative effect on natural resources and the balance of nature and its effects are already visible in the country. As critical as the effect of climate change is, it is not clear whether undergraduates are aware of what climate change is or its effect, hence this study.

\section{Statement of the Problem}

Climate change is one of the greatest threats facing human kind today and it has lots of implications for the survival of mankind. As an ecological being, man needs a conducive environment for effective and fruitful living, but human is increasingly influencing the climate and the earth's temperature in so many ways thereby making the environment unhealthy. Information is power. There are opportunities for students to develop their understanding of sustainable development within the school curriculum. Nonetheless, there appears to be scarcity of research on students' awareness and sustainability development and its integration in the school curriculum especially in Nigeria, hence this study.

\section{Purpose of the Study}

The purpose of the study is to assess undergraduates' level of awareness of climate change and sustainable development in University of Ibadan, Ibadan and Ladoke Akintola University of Technology, Ogbomoso in Oyo State, Nigeria. University of Ibadan is owned by the Federal Government while Ladoke Akintola University of Technology is owned by Oyo State.

Therefore the specific objectives of this study are to:

a. assess the level of climate change awareness among undergraduate students;

b. determine undergraduates' perception on climate change and sustainable development;

c. investigate undergraduates' source of information on climate change and sustainable development;

d. determine the level of climate change awareness of undergraduates based on gender; and

e. examine the level climate change awareness among undergraduates based on school ownership 


\section{Scope of the Study}

The study focused on undergraduates' level of awareness of climate change and sustainable development in University of Ibadan, Ibadan and Ladoke Akintola University of Technology, Ogbomoso, Oyo State.

\section{Research Questions}

1. What is the level of awareness on climate change among undergraduates?

2. How do undergraduates perceive climate change and sustainable development?

3. How accessible are undergraduates to sources of information on climate change and sustainable development.

4. Are there differences in the level of awareness of undergraduates on the concept of climate change based on gender?

5. Are there differences in the level of awareness of undergraduates on the concept of climate change based on school ownership?

\section{Research Hypothesis}

1. Level of climate change awareness among undergraduates is not significant;

2. Undergraduates perception of climate change and sustainable development is not significant;

3. Accessibility of undergraduates sources of information on climate change and sustainable development is not significant;

4. Level of awareness of undergraduates on the concept of climate change based on gender is not significant; and

5. Level of awareness of undergraduates on the concept of climate change based on school ownership is not significant.

\section{Research Methodology}

This discussed the study design, population, sample and sample procedures, research instrument, validity and reliability of the instrument. The study adopted a descriptive survey design which requires the opinion to respond to some variables. The population of the study comprised of all undergraduates in University of Ibadan, Ibadan and Ladoke Akintola University of Technology, Ogbomoso in Oyo State. The sample constituted 300 undergraduates' purposively selected from University of Ibadan (150) and Ladoke Akintola University of Technology (150) in Oyo State using purposive random sampling technique. The research instrument was a questionnaire developed by the researcher and it was titled 'Awareness of Climate Change and Sustainable Development Questionnaire Among Undergraduates' (ACCSDUS) and was used to collect data from the subjects. The instrument rated on a 4-point Likert-type scale. The questionnaire was divided into two sections A and B. Section A focused on the respondent's bio-data such as age, sex, level, etc. This will enable the researcher in preliminary analysis. Section B consisted of some set of questions which were specifically tailored at examining awareness of climate change and sustainable development among undergraduates in tertiary institutions. For the purpose of this research work the questionnaire was rated on a 4 point Likert scale with such category as strongly agree, agree, strongly disagree, disagree in order to efficiently elicit the exact responses from the respondent.

\section{Validity /Reliability of the Research Instrument}

The research instrument was validated by two experts. Content and construct validity was obtained by the help of other experts. All corrections and constructive criticism raised by the experts were taken into consideration in the preparation of the final version of the instrument. Reliability within the survey was obtained by calculating the correlation coefficient for each scale. The Cronbach's alpha coefficient is used and ranges from 0.69 to 0.78 .

The research instrument which was the questionnaire was personally administered by the researchers to the respondents in their various institutions of learning. It must be noted that in administering the questionnaire, respondents were informed that confidentiality will be maintained. The respondents were then required to complete the questionnaire as sincerely as they could. 300 copies of the questionnaire were administered and they were all filled and collected back for further analysis. A sample of the questionnaire is shown in Appendix I. 
Table 1. Determining the Level of Awareness of Undergraduates on the Concept of Climate Change

\begin{tabular}{lccc}
\hline \multicolumn{1}{c}{ Parameter } & Classification & Frequency & Percentage (\%) \\
\hline Climate change is happening & Yes & 288 & 97.0 \\
& No & 9 & 3.0 \\
Climate change manifests in diverse ways in & Total & 297 & 100 \\
the world & Yes & 279 & 94.3 \\
& No & 17 & 5.7 \\
We are already experiencing the impacts of & Total & 296 & 100 \\
climatic change & Yes & 269 & 92.1 \\
& No & 23 & 7.9 \\
I see climate change to be of immediate and & Total & 292 & 100 \\
urgent concern & Yes & 249 & 85.6 \\
& No & 42 & 14.4 \\
Climate change is a threat to sustainable & Total & 291 & 100 \\
development & Yes & 261 & 89.7 \\
& No & 30 & 10.3 \\
There are climate change research agencies & Total & 291 & 100 \\
at both National and global levels that I & Yes & 254 & 86.7 \\
know & No & 39 & 13.3 \\
\hline
\end{tabular}

Table 1 determines the level of awareness of undergraduates on the concept of climate change. The result indicated that $97 \%$ agreed that climate change is happening while 3\% disagreed. Also $94.3 \%$ agreed that climate change manifests in diverse ways in the world while 5.7\% disagreed. $92.1 \%$ also believed that we are already experiencing the impacts of climate change while $7.9 \%$ still disagreed. It is also believed by $85.6 \%$ that climate change should be of immediate and urgent attention while $14.4 \%$ disagreed. $89.7 \%$ believed that climate change is a threat to sustainable development while $10.3 \%$ disagreed. Also $86.7 \%$ believed that there are climate change research agencies at both National and Global levels while $13.3 \%$ believed that there are no research agencies at both National and Global levels.

Table 2. Undergraduates Perception of Climate Change and Sustainable Development

\begin{tabular}{|c|c|c|c|}
\hline Parameter & Classification & Frequency & Percentage (\%) \\
\hline \multirow[t]{3}{*}{ Climate change is more harmful than beneficial } & Yes & 239 & 87.2 \\
\hline & No & 35 & 12.8 \\
\hline & Total & 274 & 100 \\
\hline \multirow{3}{*}{$\begin{array}{l}\text { Climate change is caused mostly by human } \\
\text { activities, not natural changes in the } \\
\text { environment }\end{array}$} & Yes & 226 & 78.2 \\
\hline & No & 63 & 21.8 \\
\hline & Total & 289 & 100 \\
\hline \multirow[t]{3}{*}{ Climate change increases surface temperature } & Yes & 247 & 85.8 \\
\hline & No & 41 & 14.2 \\
\hline & Total & 288 & 100 \\
\hline \multirow[t]{3}{*}{ Climate change causes rise in sea levels } & Yes & 233 & 80.6 \\
\hline & No & 56 & 19.4 \\
\hline & Total & 289 & 100 \\
\hline \multirow{3}{*}{$\begin{array}{l}\text { Climate change increases the intensity of } \\
\text { extreme weather events like heat waves, } \\
\text { tornadoes, hurricanes and heavy rainfalls }\end{array}$} & Yes & 255 & 88.2 \\
\hline & No & 34 & 11.8 \\
\hline & Total & 289 & 100 \\
\hline \multirow{3}{*}{$\begin{array}{l}\text { Climate change leads to longer and more } \\
\text { drought }\end{array}$} & Yes & 225 & 78.7 \\
\hline & No & 61 & 21.3 \\
\hline & Total & 286 & 100 \\
\hline \multirow[t]{3}{*}{ Climate change leads to coastal erosion } & Yes & 225 & 80.4 \\
\hline & No & 55 & 19.6 \\
\hline & Total & 280 & 100 \\
\hline Climate change influences agricultural yields & Yes & 228 & 79.2 \\
\hline
\end{tabular}




\begin{tabular}{llll}
\hline negatively & No & 60 & 20.8 \\
& Total & 288 & 100 \\
Climate change results in acidification of & Yes & 222 & 77.1 \\
oceans thereby creating drops in fishing yields & No & 66 & 22.9 \\
& Total & 288 & 100 \\
Climate change poses threats to food security & Yes & 226 & 78.7 \\
& No & 61 & 21.3 \\
Climate change causes economic depression & Total & 287 & 100 \\
& Yes & 223 & 76.9 \\
& No & 67 & 23.1 \\
\hline
\end{tabular}

Table 2 determines the perception of undergraduates on the concept of climate change. The result indicated that $87.2 \%$ agreed that climate change is more harmful than beneficial while $12.8 \%$ disagreed. Also $78.2 \%$ agreed that climate change is caused mostly by human activities, not natural changes in the environment while $21.8 \%$ disagreed. $85.8 \%$ also believed that climate change increases surface temperature while $14.2 \%$ still disagreed. It is also believed by $83.8 \%$ that climate change causes rise in sea levels while $14.2 \%$ disagreed. $88.2 \%$ believed that climate change increases the intensity of extreme weather events like heat waves, tornadoes, hurricanes and heavy rainfalls while $11.8 \%$ disagreed. Also $78.7 \%$ believed that climate change leads to longer and more drought while $21.3 \%$ do not agree. $80.4 \%$ agreed that climate change leads to coastal erosion while $19.6 \%$ disagreed. $79.2 \%$ believed that climate change influences agricultural yields negatively while $20.8 \%$ disagreed. Also $77.1 \%$ believed that climate change results in acidification of oceans thereby creating drops in fishing yields while $22.9 \%$ disagreed. $78.7 \%$ believed that climate change poses threats to food security while $21.3 \%$ disagreed. Also $76.9 \%$ believed that climate change causes economic depression while $23.1 \%$ disagreed.

Table 3 determines the accessibility of undergraduates to sources of information on climate change and sustainable development. $87.2 \%$ agreed that they had access to information on climate change and sustainable development through the subjects taken by undergraduates in their secondary school days while $12.8 \%$ disagreed. $82.4 \%$ agreed that they obtained access to information on climate change and sustainable development through the courses taken at the university while $17.6 \%$ disagreed. $70.1 \%$ agreed that they had access to information on climate change and sustainable development through literature books that they read while $29.9 \%$ disagreed. $74.4 \%$ agreed that they obtained access to information on climate change and sustainable development through school pamphlets and reading materials while $25.6 \%$ disagreed. $79.8 \%$ agreed that they obtained access to information on climate change and sustainable development through research reports and periodicals in the library while $20.2 \%$ disagreed. Also $93.4 \%$ obtained access to information on climate change and sustainable development through documentaries on the television while $6.6 \%$ disagreed. $88.9 \%$ agreed that they obtained access to information on climate change and sustainable development through broadcasts and enlightenment programmes on radio and television while $11.1 \%$ disagreed. $86.7 \%$ agreed that they obtained access to information on climate change and sustainable development through newspapers and magazines while $13.3 \%$ disagreed. $74.9 \%$ agreed that they obtained access to information on climate change and sustainable development through parents and guardians while 25.1 disagreed. $73.2 \%$ agreed that they obtained access to information on climate change and sustainable development through peers, friends, siblings and relatives while $26.8 \%$ disagreed. $77.1 \%$ agreed that they obtain access to information on climate change and sustainable development through seminars and workshops that they attended while $22.1 \%$ disagreed. Also $75.3 \%$ agreed that while 24.7 disagreed. $90.6 \%$ agreed that they obtained access to information on climate change and sustainable development through internet and World Wide Web while 9.4\% disagreed. $82.3 \%$ agreed that they obtained access to information on climate change and sustainable development through computer networking while $17.7 \%$ disagreed. $82.2 \%$ agreed that they obtained access to information on climate change and sustainable development through multi-functional mobile phones while $17.8 \%$ disagreed. Also $74.7 \%$ agreed that I obtain access to information on climate change and sustainable development through electronic objects or simulations while $25.3 \%$ disagreed. 
Table 3. Accessibility of Undergraduates to Sources of Information on Climate Change and Sustainable Development

\begin{tabular}{|c|c|c|c|}
\hline Parameter & Classification & Frequency & Percentage (\%) \\
\hline I obtain access to information on climate change and & Yes & 252 & 87.2 \\
\hline sustainable development through the subjects taken in my & No & 37 & 12.8 \\
\hline secondary school days & Total & 289 & 100 \\
\hline I obtain access to information on climate change and & Yes & 238 & 82.4 \\
\hline sustainable development through the courses taken at the & No & 51 & 17.6 \\
\hline university & Total & 289 & 100 \\
\hline I obtain access to information on climate change and & Yes & 202 & 70.1 \\
\hline \multirow[t]{2}{*}{ sustainable development through literature books that I read } & No & 86 & 29.9 \\
\hline & Total & 288 & 100 \\
\hline I obtain access to information on climate change and & Yes & 215 & 74.4 \\
\hline sustainable development through school pamphlets and & No & 74 & 25.6 \\
\hline reading materials & Total & 289 & 100 \\
\hline I obtain access to information on climate change and & Yes & 229 & 79.8 \\
\hline sustainable development through research reports and & No & 58 & 20.2 \\
\hline periodicals in the library & Total & 287 & 100 \\
\hline I obtain access to information on climate change and & Yes & 268 & 93.4 \\
\hline sustainable development through documentaries on the & No & 19 & 6.6 \\
\hline television & Total & 287 & 100 \\
\hline I obtain access to information on climate change and & Yes & 255 & 88.9 \\
\hline sustainable development through broadcasts and & No & 32 & 11.1 \\
\hline enlightenment programmes on radio and television & Total & 287 & 100 \\
\hline I obtain access to information on climate change and & Yes & 247 & 86.7 \\
\hline \multirow[t]{2}{*}{ sustainable development through newspapers and magazines } & No & 38 & 13.3 \\
\hline & Total & 285 & 100 \\
\hline I obtain access to information on climate change and & Yes & 215 & 74.9 \\
\hline \multirow[t]{2}{*}{ sustainable development through parents and guardians } & No & 72 & 25.1 \\
\hline & Total & 287 & 100 \\
\hline I obtain access to information on climate change and & Yes & 210 & 73.2 \\
\hline sustainable development through peers, friends, siblings and & No & 77 & 26.8 \\
\hline relatives & Total & 287 & 100 \\
\hline I obtain access to information on climate change and & Yes & 222 & 77.1 \\
\hline sustainable development through seminars and workshops & No & 66 & 22.9 \\
\hline that I attend & Total & 288 & 100 \\
\hline I obtain access to information on climate change and & Yes & 217 & 75.3 \\
\hline \multirow[t]{2}{*}{ sustainable development through excursions and field trips } & No & 71 & 24.7 \\
\hline & Total & 288 & 100 \\
\hline I obtain access to information on climate change and & Yes & 259 & 90.6 \\
\hline sustainable development through internet and world wide & No & 27 & 9.4 \\
\hline web & Total & 286 & 100 \\
\hline I obtain access to information on climate change and & Yes & 237 & 82.3 \\
\hline \multirow[t]{2}{*}{ sustainable development through computer networking } & No & 51 & 17.7 \\
\hline & Total & 288 & 100 \\
\hline I obtain access to information on climate change and & Yes & 236 & 82.2 \\
\hline sustainable development through multi-functional mobile & No & 51 & 17.8 \\
\hline phones & Total & 287 & 100 \\
\hline I obtain access to information on climate change and & Yes & 215 & 74.7 \\
\hline sustainable development through electronic objects or & No & 73 & 25.3 \\
\hline simulations & Total & 288 & 100 \\
\hline
\end{tabular}


Table 4. Differences in the Level of Awareness of Undergraduates on the Concept of Climate Change and Sustainable Development Based on Gender

\begin{tabular}{lllllll}
\hline Sex & $\mathrm{N}$ & Mean & Std. Deviation & $\mathrm{t}$ & $\mathrm{df}$ & Sig. \\
\hline Male & 103 & 1.0485 & 0.21596 & 34 & 25 & 0.73 \\
Female & 154 & 1.0584 & 0.23534 & 1 & 5 & 3 \\
\hline
\end{tabular}

The t-test is used to test for a significant difference between genders on the level of awareness of undergraduates on the concept of climate change and sustainable development. A significant value of 0.733 which is greater than 0.05 the critical alpha value. We therefore concluded by accepting the null hypothesis that there is no significance difference between genders on level of awareness of undergraduates on the concept of climate change and sustainable development based on gender?

Table 5. Level of Awareness of Undergraduates on the Concept of Climate Change based on University Ownership

\begin{tabular}{lllllll}
\hline University ownership & $\mathrm{N}$ & Mean & Std. Deviation & $\mathrm{T}$ & $\mathrm{df}$ & Sig. \\
\hline Government & 111 & 1.0180 & 0.13362 & 2.49 & 25 & 0.01 \\
Private & 141 & 1.0922 & 0.29034 & 1 & 0 & 3 \\
\hline
\end{tabular}

The t-test is used to test for a significant difference based on school ownership. A significant value of 0.013 which is greater than 0.05 the critical alpha value. We therefore concluded by accepting the null hypothesis that there is no significance difference between level of awareness of undergraduates' on the concept of climate change based on University Ownership.

\section{Discussion}

The findings of this study revealed that majority of the respondents are aware of climate change and sustainable development and the level of awareness is significant. The personal experience gathered greatly influenced the respondent's awareness. The results were similar to the finding of Olajide et al. (2011) who found knowledge of global warning among undergraduate students of Obafemi Awolowo University (OAU), Ile Ife, Nigeria, depending on their ages and gender. It also is in agreement with Bell (2012) who affirmed that sustainable development is gradually becoming a household name and awareness is growing on how individuals can promote well-being and make the world a comfortable place to live in. The hypotheses tested by the study further buttressed the point that a strong relationship exists between undergraduates level of awareness on climate change and sustainability development. However there is the need to enlighten the entire public on climate change issues and its consequences.

Another study conducted in Philippines showed that the capacity of students to generate researches on climate change adaptation (ACA) and disaster risk reduction management (DRRM) depended on their former exposure to relevant areas of climate change (Pesimo, 2013). It was suggested that topics on ACA and DRRM should be integrated in the biological and earth sciences. From the aforesaid it may be necessary to introduce a general study course in the University for Climate Literacy. Research findings also showed in a research in Ankara (Turkey) on environmental sensitivity and awareness of university students that even though students take many courses on the environmental issues, their environmental awareness and environmentally responsible behaviours are lower than the expected and students' grades show no significance on the results. The first and fourth year students of landscape architecture, town and regional planning and environmental engineering undergraduate programs at universities throughout Ankara, Turkey were selected as participants since these programmes' curricula focus on environment. It is concluded that environmental knowledge do not always influence awareness and behavioral intentions, a national strategy is needed for environmental education in higher education, and current curricula should be reconsidered in terms of effectiveness (Ouz et al., 2010).

In a similar research in Adawawa State, Nigeria, aimed at examining the general level of awareness of climate change impacts and adaptations, the results showed that there is a high level of awareness of climate change among the citizens of the state (Adebayo et al., 2013). This is similar to the findings of Ishaya and Abaje (2008) in Jemaa Local Government Area of Kaduna State, Nigeria that majority of the local people are aware of changes in climate. Almost all respondents, both males and females, were aware of climate change even if they don't know the causes. In the State, evidence of climate change includes delayed onset date of rains, increase in number of dry days during 
the raining season, decrease in annual rainfall and increase in maximum temperature (Adebayo, 2010; 2011). Respondents' could see that temperature and length of dry season are increasing while rainfall is decreasing. In Nigeria in general, according to experts' reports the mean temperature is increasing while annual rainfall is decreasing (Odjugo, 2009; Adebayo, 2010; Umar, 2011). It was also reported that in Tharu community of Nepal suffered loss of timber and firewood species due to climate change (Maharjan et al., 2011).

In India, a survey was conducted involving school children, undergraduate students and adults from various sectors to know the level awareness of climate change and its effects. The survey was conducted in Metropolitan city Mumbai and semi urban area of Panvel near Mumbai. Many school children and undergraduate students reported that they are aware of climate change but not aware of its problems and how to tackle it. Whereas fishermen of Panvel area agreed that climate change has affected fishery harvest but not sure which factor of climate change caused it. More than $50 \%$ respondents said that they are getting information of climate change from print and electronic media. However, most of these people are unaware of health problems caused by climate change. Fishermen and coastal people were not aware of ocean acidification and possible damage to the ocean resources due to ocean acidification. Furthermore, most of the respondents did not know how to minimize climate change. The authors concluded that in Maharashtra still there is need to make people literate about climate change and its effects on human health (Kulkarni et al., 2016).

\section{Summary}

The study was conducted to assess undergraduates' level of awareness on climate change and sustainable development. The study determined the level of awareness of undergraduate students, factors that influenced their awareness, and their sources of information on climate change and sustainable development. In addition, the study examined factors of gender and school ownership.

\section{Conclusion}

Prevailing human activities as well as natural phenomena constitute agents of climate change and they must be controlled. This justifies the need for awareness and enlightenment on climate change and sustainable development.

All countries are vulnerable to the adverse impacts of climate change; hence it is imperative to see that every individual is knowledgeable and well informed. Questions about global warming, unstable weather, and climate crisis should be asked and solutions sought. Awareness on climate change among all and sundry is pertinent and education is an essential component and catalyst for responding to global climate in its efficacy to raise awareness and promote knowledge and skills development on climate issues and related concepts.

\section{References}

Adebayo, A. A. (2010). Climate: Resource and Resistance to Agriculture. Eighth Inaugural Lecture, Federal University of Technology, Yola.

Adebayo, A. A., Mubi, A. M., Zemba, A. A., \& Umar, A. S. (2013). Awareness of Climate Change Impacts and Adaptation in Adama wa State, Nigeria. International Journal of Environment, Ecology, Family and Urban Studies (IJEEFUS), 3(1), 11-18.

Adebayo, A.A. (2011). Adamawa State Climate Change Action Plan. Paper presented at the stake holder workshop on State Climate change action plan organised by UNDAF Adamawa state and Bright Light Educational Services, Yola.

Aliyu, B. N. (2009). Local Knowledge in Climate Change and the Nigeria Environment held at the Department of Geography, University of Nigeria, Nsukka, Nigeria.

Bell, D.V.J. (2012). The Challenge of Sustainability and the Role of Education. Keynote Presentation to Association Quebecoise de Pedagogie Collegiale (AQPC) June 2012.Faculty of Environmental Studies York University. Empowering educators for a sustainable future. United Nations Economic Commission For Europe. Retrieved from http://en.wikipedia.org/wiki/Climate_change

Intergovernmental Panel on Climate Change (IPCC) (2007a). Climate Change 2007. The Physical Science Basis: Summary for Policy Makers: IPCC, WMO. Contribution of the Working Group 1 to the Fourth Assessment Report of the IPCC. In Solomon, S. D., Qin, M., Manning, Z., Chen, M., Marquis, K. B., Averyt, T. M. and Miller, H. L. (eds.), Cambridge University Press, Cambridge, United Kingdom and New York, NY, USA. pp. 
996.

Intergovernmental Panel on Climate Change (IPCC) (2007b). Climate Change 2007. Impact, adaptation and vulnerability. Contribution of Working Group II to the Fourth Assessment Report of the IPCC. Parry, M. L., Canziani, O. F., Palutikof, J. P., van der Linden, P. J. and Hanson, C. E. Cambridge, UK, Cambridge University Press. pp. 976.

Ishaya, S., \& Abaje I.B. (2008). Indigenous people's perception on climate change and adaptation strategies in Jemma LGA of Kaduna state. Journal of Geography and Regional Planning, 1(18), 138-143.

Knutson, T. (2011). Thinking Big on Climate Issues.Oceanic and Atmospheric Research. National Oceanic and Atmospheric Administration. $\quad$ ArticleID/10285. Retrieved from http://research.noaa.gov/InDepth/MeetOurScientists/CurrentScientist/TabId/546/ArtMID/2688/ArticleID/10285 /Knutson-Tom.aspx. On 08/05/2015

Kulkarni, B. G., Kulkarni, M., Kupekar, S., \& Babar, A. (2016). Climate change and people in State of Maharashtra. Abstract of the Global Climate Observation System (GCOS) Conference: The Road to the Future: Shaping the Next GCOS Implementation Plan, 2-4 March, 2016, Amsterdam. www.gcos-science.org.

Maharjan, S.K., Sidgel, E.R., Sthapit, B.R., \& Regmi, B.R. (2011). Tharu community's perception on climate change and their adaptive initiations to withstand its impacts in Western Terai of Nepal. International NGO Journal, $6(2), 35-42$.

Marty, R., \& Yokochi, R. (2006). Water in the early earth. Reviews in Mineralogy and Geochemistry, 62, 421-450. http://dx.doi.org/10.2138/rmg.2006.62.18

Mendelsohn, R., Dinar, A., \& Williams, L. (2006). The distributional impact of Climate Change on rich and poor countries. Environment and Development Economics, 11, 159-178. http://dx.doi.org/10.1017/S1355770X05002755

Nath, B. (2009). Instilling Environmental Awareness in Undergraduate University Students. Environmental Education and Awareness - Vol 1, Nath, B., European Centre for Pollution Research (London, UK), ed., Encyclopedia of Life Support Systems in Partnership with UNESCO, pp. 244 - 253.

Odjugo, P.A.O. (2009). The impact of climate change on water resources: Global and Nigerian analysis. FUTY Journal of Environment, 4(1), 59-77.

Olajide, F.O., Afolabi, O.A., Olajide, A.O, Omisore, A.G, Odunlade, A.O., \& Omobuwa, O. (2011). Knowledge about the causes, consequences and control of climate change among undergraduates of Obafemi Awolowo University, Ile-Ife. A.A. Adebayo, A.M. Mubi, A.A. Zemba and A.S. Umar in Salami A.T. and Orimoogunje O.O.I. (Eds) Environmental Research and challenge of sustainable development. OAU Press. Ile Ife.

Ouz, D., Çakci, I., \& Kavas, S. (2010). Environmental awareness of University Students in Ankara, Turkey. African Journal of Agricultural Research, 5(19), 2629-2636.

Pesimo, A. R. (2013). The Relevance of Undergraduate Thesis to Climate Change Adaptation and Disaster Risk Reduction and Management. Journal of Modern Education Review, 3(7), 561-567.

Umar, A.T. (2011). Climate change in Nigeria: Evidence from meteorological parameters. Paper presented at 2011 Association of Nigeria Geographers conference at Usman Dafodio University, Sokoto.

United States Environmental Protection Agency (USEPA) (2014). Climate Change: Basic Information. Retrieved from; http://www.epa.gov/climatechange/basics/ on 5 May, 2015.

United States Global Change Research Programme (USGCRP) (2009). Climate Literacy: The Essential Principle of Climate Science: A Guide for Individuals and Communities: A Climate-Oriented Approach for Learners of all Ages. Second Version Retrieved on 5 May, 2015 from: www.globalchange.gov 


\section{APPENDIX 1}

OBAFEMI AWOLOWO UNIVERSITY, ILE-IFE, NIGERIA

FACULTY OF EDUCATION

INSTITUTE OF EDUCATION

\section{QUESTIONNAIRE ON AWARENESS OF CLIMATE CHANGE AND SUSTAINABLE DEVELOPMENT} AMONG UNDERGRADUATES FROM TWO INSTITUTIONS IN OYO STATE

\section{Dear respondent;}

This study investigates undergraduates' awareness of climate change and sustainable development. Kindly complete this questionnaire by providing your honest response. All information provided will be treated with utmost confidentiality.

Thank you.

\section{SECTION A}

Please tick $(\sqrt{ })$ as applicable to you.

1. University ownership: Government , Private

2. Sex: Male , Female

3. Course level: 100level , 200level , 300level , 400level

\section{SECTION B}

Please use the following ratings; Strongly Agree (SA), Agree (A), Disagree (D) Strongly Disagree (SD) on the statements to indicate your response or express your opinion.

Level of awareness of climate change:

\begin{tabular}{|l|l|l|l|l|l|}
\hline S/N & Statement & SA & A & D & SD \\
\hline 1 & Climate change is happening & & & & \\
\hline 2 & Climate change manifests in diverse ways in the world & & & & \\
\hline 3 & We are already experiencing the impacts of climate change & & & \\
\hline 4 & I see climate change to be of immediate and urgent concern & & & \\
\hline 5 & Climate change is a threat to sustainable development & & & \\
\hline 6 & $\begin{array}{l}\text { There are climate change research agencies at both National and global } \\
\text { levels that I know }\end{array}$ & & & \\
\hline
\end{tabular}

Factors that influence my level of awareness on climate change

\begin{tabular}{|l|l|l|l|l|}
\hline (i). Education & & & \\
\hline 7 & $\begin{array}{l}\text { Teaching the concept of climate change in the school curriculum gives me } \\
\text { better understanding and awareness of climate change }\end{array}$ & $\begin{array}{l}\text { Membership of environmental organisations improves my awareness on } \\
\text { climate change and sustainable development. }\end{array}$ & & \\
\hline 8 & $\begin{array}{l}\text { Awareness on climate change and sustainable development comes from } \\
\text { reading about earth systems }\end{array}$ & & \\
\hline (ii). Public sources & & \\
\hline
\end{tabular}




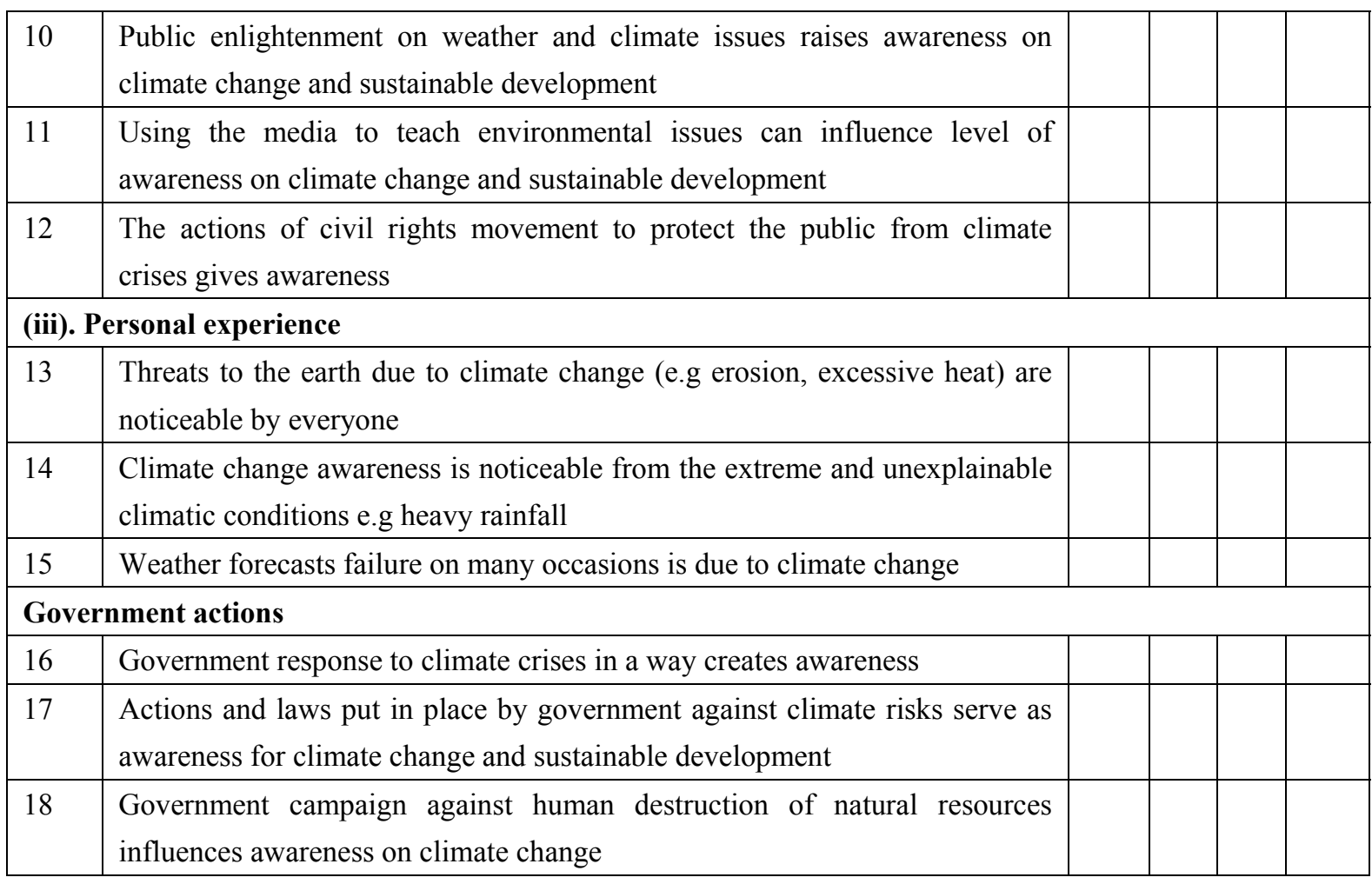

\section{Perception on climate change and sustainable development:}

\section{Climate change;}

\begin{tabular}{|c|c|c|c|c|c|}
\hline $\mathrm{S} / \mathrm{N}$ & & SA & A & $\mathrm{D}$ & SD \\
\hline 19 & Is more harmful than beneficial & & & & \\
\hline 20 & $\begin{array}{l}\text { Is caused mostly by human activities, not natural changes in the } \\
\text { environment }\end{array}$ & & & & \\
\hline 21 & Increases surface temperature & & & & \\
\hline 22 & Causes rise in sea levels & & & & \\
\hline 23 & $\begin{array}{l}\text { Causes increase in intensity of extreme weather events like heat waves, } \\
\text { tornadoes, hurricanes and heavy rainfalls }\end{array}$ & & & & \\
\hline 24 & Leads to longer and more drought & & & & \\
\hline 25 & Leads to Coastal erosion & & & & \\
\hline 26 & Influences agricultural yield negatively & & & & \\
\hline 27 & Results in acidification of oceans thereby creating drops in fishing yields & & & & \\
\hline 28 & Poses threats to food security & & & & \\
\hline 29 & Causes economic depression & & & & \\
\hline
\end{tabular}




\section{Accessibility to sources of information on climate change and sustainable development}

I obtain access to information on climate change and sustainable development through;

\begin{tabular}{|c|c|c|c|c|c|}
\hline $\mathrm{S} / \mathrm{N}$ & Statement & SA & A & $\mathrm{D}$ & SD \\
\hline \multicolumn{6}{|c|}{ (i). Education } \\
\hline 30 & The subjects taken in my secondary school days & & & & \\
\hline 31 & The courses taken at the university & & & & \\
\hline 32 & Literature books that I read & & & & \\
\hline 33 & School pamphlets and reading materials & & & & \\
\hline 34 & Research reports and periodicals in the library & & & & \\
\hline \multicolumn{6}{|c|}{ (ii). Media and home } \\
\hline 35 & Documentaries on the television & & & & \\
\hline 36 & Broadcasts and Enlightenment programmes on radio and television & & & & \\
\hline 37 & Newspapers and magazines & & & & \\
\hline 38 & Parents and guardians & & & & \\
\hline 39 & Peers, friends, siblings and relatives & & & & \\
\hline \multicolumn{6}{|c|}{ (iii). Seminars / workshops } \\
\hline 40 & Seminars and workshops that I attend & & & & \\
\hline 41 & Excursions and field trips & & & & \\
\hline \multicolumn{6}{|c|}{ (iv). ICT } \\
\hline 42 & Internet \& world wide web & & & & \\
\hline 43 & Computer networking & & & & \\
\hline 44 & Multi-functional mobile phones & & & & \\
\hline 45 & Electronic objects / simulations & & & & \\
\hline
\end{tabular}

